\title{
Editorial
}

\section{Coal and the lung}

The association between exposure to coal dust underground and increased risk of respiratory disease has been known in mining communities since at least the end of the eighteenth century, and coalworker's pneumoconiosis was described by Laennec in his famous treatise on auscultation. At that time silicosis and its complication tuberculosis were diseases only too well known among metal miners and it was reasonable to assume that the disease in coalminers was similarly due to the silica content of the coal dust. This seemed particularly sensible when chest radiography became available and the radiographic abnormalities in coalminers and in men exposed to quartz were seen to be so similar. A series of important studies in South Wales, however, carried out by the Medical Research Council (MRC) because of concern about an apparent epidemic of lung disease among coalminers in that region, led to the conclusion that the disease differed from silicosis and indeed in many cases was a consequence of exposure to dust containing little or no quartz. ${ }^{12}$ This idea received further support from the work of Gough, also in South Wales, when he described the disease in coal trimmers at the docks-men who were exposed to virtually pure coal dust. ${ }^{3}$ Since 1943 coalworkers' pneumoconiosis has been recognised as a disease separate from silicosis in Britain for the payment of industrial injuries benefits.

Further studies by the MRC in South Wales helped considerably in the understanding of this disease. Two forms, simple and complicated (or progressive massive fibrosis), were recognised, ${ }^{4}$ and there was seen to be an apparent lack of any serious functional impairment associated with the simple form. ${ }^{5}$ The relationship of the risk of progressive massive fibrosis to dust exposure was also described. $^{2}$ This work was then taken further after nationalisation of the industry in 1947 by the National Coal Board (NCB), which commenced a longitudinal study of the disease in some 30000 miners in 25 collieries throughout Britain, with the twin aims of finding out what quantities and types of dust cause pneumoconiosis and of determining what levels of dust needed to be maintained to prevent respiratory disability in the work force. Much of the credit for this ambitious and far-sighted research programme must go to Dr John Rogan, then the chief medical officer of the NCB. After 10 years of prospective research a dose-response curve could be derived relating exposure to respirable dust to risk of simple pneumoconiosis, thus providing coal industries with information on which standards could realistically be based. ${ }^{67}$ Measures to control dust levels underground based on this information, together with contraction of the workforce and shorter working hours, have contributed to the striking fall in the prevalence of coalworkers' pneumoconiosis in Britain. Nevertheless, just under 500 working and retired men each year are still certified as having the disease for the purposes of industrial injuries benefit-that is, they have category 2 simple radiographic changes or more.

So far the story seems clear. Coal dust causes a specific pneumoconiosis and the more dust you breathe the greater your risk. Reduce dust levels and exposures and you will reduce the incidence of the disease. What more then needs to be done? Three important questions remain and recent research has gone a long way towards providing answers to these. Firstly, given that there is a clear relationship between average exposure and average risk of disease, why is there so much variability in this relationship in different parts of the country? Secondly, why does the relatively benign simple pneumoconiosis sometimes progress into the disabling and potentially fatal progressive massive fibrosis? Thirdly, does exposure to coal dust increase a man's risk also of emphysema and disabling airways obstruction?

The first of these questions is proving the least easy to answer. In general, there seems to be a relationship between rank of coal (that is, an index of combustibility related approximately to carbon content) and risk of disease-high-rank, high-carbon coals being most dangerous. ${ }^{89}$ This fits well with the observed high prevalence of disease in South Wales and also with the pattern in the United States. Men exposed in the past to high-rank coals in Britain, however, have also traditionally been exposed to very high dust levels, and high-rank coal is rather non-toxic when examined in vitro. Perhaps the predominance of disease in the high-rank coalfields will turn out to be due simply to exposure to larger amounts of dust than elsewhere, the doses having been underestimated in the epidemiological research. Or perhaps there is some characteristic of high-rank dusts that makes them less easily cleared from the lungs. Further investigation of this problem 
is required. Paradoxically, lower-rank coals contain more quartz and silicates and might be thought on this basis to be potentially more toxic. There is some evidence that the toxicity of quartz is interfered with in animals and in vitro if it is mixed with coal and silicates, ${ }^{10}$ so perhaps inhalation of the inevitable mixture in coal dust does afford some protection from the harmful effects of quartz. Nevertheless, it is now clear that coalminers working at the face as well as in tunnelling may occasionally be exposed to relatively high levels of quartz and develop a progressive form of pneumoconiosis indistinguishable from silicosis. ${ }^{11} 12$ Much of the variability in prevalence of pneumoconiosis in different parts of Britain is likely to be related to differences in total exposure to dust and in the composition of that dust. The differences should become less significant with progressive improvement in control of coal and quartz dust levels underground.

The second question, which essentially concerns the causes of progressive massive fibrosis, also remains incompletely answered. Recent studies have confirmed that there are two exteme pathological types of progressive massive fibrosis (if we exclude the rare Caplan's syndrome), most individuals showing patterns somewhere in between these extremes. ${ }^{13}{ }^{14}$ One is exemplified by the typical appearances in a South Wales coalminer, where the lesions are large amorphous, pigmented masses with a relatively sparse cellular response and often surrounded by bullous emphysema. They contain fibronectin and relatively little collagen. ${ }^{1516}$ The other is more typically found in men who have worked in some parts of the Midlands, the lesion of progressive massive fibrosis being formed by agglomeration of smaller, more cellular lesions containing irregularly whorled collagen. ${ }^{13}$ Such lesions may resemble or be indistinguishable from those of silicosis, and they are probably a response to quartz exposure, in keeping with epidemiological observations. ${ }^{11}{ }^{12}$ Thus one pathway to progressive massive fibrosis seems explicable on the basis of quartzinduced damage to macrophages, with the release of fibrogenic factors and deposition of collagen. Since quartz is poorly removed once inhaled, the development of progressive massive fibrosis even years after exposure has ceased ${ }^{17}$ is relatively easy to understand, particularly if carbon or silicates inhaled concurrently interfere with the toxicity of quartz until they have been selectively removed by the lung's defences. This, however, still leaves us to explain the frequent occurrence of progressive massive fibrosis in men exposed to dust with little or no quartz content, as in South Wales. This remains a mystery, though we have observed that the lungs of men with progressive massive fibrosis from South
Wales contain very much more dust than those of men with the condition who have worked elsewhere. Perhaps there is some characteristic of such high- $\bar{O}$ rank coal dusts that prevents their elimination from the lung or that causes them to block the lymphatic pathways, thus resulting in dense local accumulation and a non-fibrogenic tissue response. There remains plenty of scope for further research.

The third question can now be regarded as answered. There is a clear relationship between measured exposure to respirable coal dust and both FEV ${ }_{1}^{18}$ and decline in FEV over an 11-year period. ${ }^{19}$ The effect of the highest dust exposures, two to three times what a man would now be exposed to if he worked continuously at the highest allowable levels for the whole of his working life, was roughly comparable with the average effect of $O$ being a cigarette smoker. ${ }^{19}$ Exposures to current British dust levels are likely to have a much smaller $\vec{D}$ effect and studies are under way to measure this. What this decline in $\mathrm{FEV}_{1}$ is related to in pathological terms is also becoming clearer. Postmortem studies have now shown convincingly, ${ }^{20}$ confirming earlier suggestive findings, ${ }^{21}$ that coalminers, at least in South Wales, have more emphysema than control subjects. Moreover, it has been shown that the more coal dust is present in a coalminer's lung the greater the risk that the lung will show centriacinar emphysema. ${ }^{22}$ Interestingly, the presence of quartz seems to reduce the risk of emphysema. The more emphysema was present in a lung the lower was that man's $\mathrm{FEV}_{1}$ in life. ${ }^{21}{ }^{22}$ This leads to the interesting hypothesis that inhalation of coal dust may have two effects, each able to be modified by the other minerals with which the coal is associated. On one case, where there is little quartz, it may accumulate in the lung, stimulating a mild cellular response which may lead to both emphysema (perhaps through elastase release from neutrophils and macrophages) and a necrotic, non-collagenous type of progressive massive fibrosis. At the other extreme, coal and quartz $\frac{7}{0}$ may interefere with each other's effects, quartz in high proportions producing fibrosis rapidly, while in N lower proportions, though interfered with by other minerals, it may gradually become active and cause fibrosis later as the coal is removed by the lung's defences. ${ }^{10}$

It is encouraging to see that this research by the MRC and the NCB, and also in recent years by the $\mathbb{D}$ United States Public Health Service $e^{23}$ and the $\stackrel{?}{+}$ German coal industry, ${ }^{2 s}$ has led to important $T$ advances in understanding which have been of direct advantage to the men on whom society depends for $\stackrel{\square}{\square}$ its coal. While coalmines will never be safe or pleas- $\stackrel{\unrhd}{\varrho}$ ant places to work, at least a man can now contemplate a lifetime underground with only a very small 
risk of suffering respiratory impairment as a result. Continued application of the results of the research should see this risk almost disappear; with relaxation of vigilance in dust control, on the other hand, the miners would once again be required to pay for our coal with their health.

\section{ANTHONY SEATON Institute of Occupational Medicine Edinburgh}

Note: Some of the research discussed above has so far been published only in abstract form. Full details, in the Institute of Occupational Medicine's series of Technical Memoranda, are available from Dr Seaton on request.

\section{References}

'Medical Research Council. Chronic pulmonary disease in South Wales coalminers. I-Medical studies. London: HMSO, 1942. (Special Report Series No. 243.)

${ }^{2}$ Medical Research Council. Chronic pulmonary disease in South Wales coalminers. II-Environmental studies. London: HMSO, 1943. (Special Report Series No. 244.)

${ }^{3}$ Gough J. Pneumoconiosis of coal trimmers. J Path Bact 1940;51:277-85.

${ }^{4}$ Fletcher CM, Mann KJ, Davies I, Cochrane AL, Gilson JC, Hugh-Jones $P$. The classification of the radiographic appearances in coalminers' pneumoconiosis. $J$ Fac Radiol (Lond) 1949;1:40-60.

${ }^{5}$ Gilson JC, Hugh-Jones P. Lung function in coalworkers' pneumoconiosis. London: HMSO, 1955. (Medical Research Council Special Report Series No. 290.)

- Jacobsen M, Rae S, Walton WH, Rogan JM. The relation between pneumoconiosis and dust exposure in British coal mines. In: Walton WH, ed. Inhaled particles III. Old Woking, Surrey: Unwin, 1971: 903-19.

${ }^{7}$ Hurley JF, Burns J, Copland L, Dodgson J, Jacobsen M. Coalworkers' simple pneumoconiosis and exposure to dust at 10 British Coal mines. $\mathrm{Br} J$ Ind Med 1982;39:120-7.

${ }^{8}$ Morgan WKC. Prevalance of coalworkers' pneumoconiosis. Am Rev Respir Dis 1968;98:306-10.

${ }^{9}$ Bennett JG, Dick JA, Kaplan YS, et al. The relationship between coal rank and the prevalence of pneumoconiosis. Br J Ind Med 1979;36:206-10.
${ }^{10}$ Martin JC, Daniel H, Le Bouffant L. Short- and longterm experimental study of the toxicity of coalmine dust and some of its constituents. In: Walton WH, ed. Inhaled particles IV. Oxford: Pergamon Press, 1977:361-70.

"Seaton A, Dick JA, Dodgson J, Jacobsen M. Quartz and pneumoconiosis in coalminers. Lancet 1981;ii:12725.

12 Jacobsen M, MacLaren WM. Unusual pulmonary observations and exposure to coalmine dust: a case-control study. In: Walton WH, ed. Inhaled particles $V$. Oxford: Pergamon Press, 1982: 753-63.

${ }^{13}$ Davis JMG, Chapman J, Collings P, et al. Variations in the histological patterns of the lesion of coalworkers' pneumoconiosis in Britain and their relation to lung dust content. Am Rev Respir Dis (in press).

${ }^{14}$ Ruckley VA,Chapman J, CollingsP, et al. Autopsy studies of coalminers' lungs-phase 2. Report No TM/81/18. Edinburgh: Institute of Occupational Medicine, 1981

15 Wagner JC, Wusteman FS, Edwards JH, Hill RJ. The composition of massive lesions in coal miners. Thorax 1975;30:382-8.

${ }^{16}$ Wagner JC, Burns J, Munday DE, McGee J O'D. Presence of fibronectin in pneumoconiotic lesions. Thorax 1982;37:54-6.

${ }^{17}$ Soutar CA, MacLaren W. A follow-up study of pneumoconiosis in miners and ex-miners. Thorax 1982;37:780-1.

${ }^{18}$ Rogan JM, Attfield MD, Jacobsen M, Rae S, Walker DD, Walton WH. Role of dust in the working environment in development of chronic bronchitis in British coal miners. In: Walton WH, ed. Inhaled particles III. Old Woking, Surrey: Unwin, 1971:883-94.

${ }^{19}$ Love RG, Miller BG. Longitudinal study of lung function in coalminers. Thorax 1982;37:193-7.

${ }^{20}$ Cockcroft A, Seal RME, Wagner JC, Lyons JP, Ryder R, Andersson N. Post-mortem Studies of emphysema in coalworkers and non-coalworkers. Lancet 1982;ii:600-3.

${ }^{21}$ Lyons JP, Ryder R, Campbell H, Gough J. Pulmonary disability in coalworkers' pneumoconiosis. $\mathrm{Br}$ Med J 1972;i:713-6.

${ }^{22}$ Ruckley VA, Seaton A. Emphysema in coalminers. Thorax 1981;36:716.

${ }^{23}$ Kibelstis JA, Morgan JE, Reger R, Lapp NL, Seaton A, Morgan WKC. Prevalence of bronchitis and airways obstruction in American bituminous coal miners. Am Rev Respir Dis 1973;108:886-93.

${ }^{24}$ Hankinson JL, Reger RB, Morgan WKC. Maximal expiratory flows in coal miners. Am Rev Respir Dis 1977;116:175-80.

${ }^{25}$ Reisner MTR. Results of epidemiologic studies on the progression of coal workers' pneumoconiosis. Chest 1980;72;suppl:406-7. 